\title{
Lithodependence of partly transported weathering horizons above a migmatite-diabase contact in Central Bahia State, Brazil
}

\author{
Andreas Marker ${ }^{\mathrm{a}}$, Joaquim J. de Oliveira ${ }^{\mathrm{a}}$, Werner Schellmann ${ }^{\mathrm{b}}$ \\ "Instituto de Geociencias, UFBa, Rua Caetano Moura, I23, Salvador, Brazil \\ ${ }^{\mathrm{b}}$ Bundesanstalt für Geowissenschaften und Rohstoffe, Postfach 5101 53, 30631 Hannover, Germany
}

\begin{abstract}
In the semi-arid region of Central Bahia, the weathering cover above a concealed migmatitediabase contact consisting of a loose sandy-clayey surface layer and an indurated gravelly laterite shows distinct chemical and mineralogical relationships to the underlying parent rocks. High concentrations of $\mathrm{Fe}, \mathrm{V}, \mathrm{Mn}, \mathrm{Cu}, \mathrm{Co}$ and $\mathrm{Ni}$ characterize the weathering material above the diabase. In the overlying laterite layer, a chemical dispersion of most of these elements towards the migmatite can be observed. On the other hand, the weathering material above the diabase shows abundance of primary quartz, zircon and rutile derived from the migmatite. The evolution of the weathering cover is believed to be controlled by colluvial intermixing and vertical homogenization of partly transported weathering material, being followed by lateral chemical dispersion during laterite formation. Thus, the weathering horizons obliterate the chemical signal of the parent rocks increasingly from the bottom to the top of the profile. Similar profiles can be expected in most savannah-type regions and, therefore their identification is relevant for geochemical exploration.
\end{abstract}

\section{Introduction}

Chemical weathering and physical redistribution of weathering products are important processes controlling composition, structure and texture of lateritic material, which overlies various types of parent rock. Surficial layers although in many cases separated from underlying layers by a stone-line, may reveal distinct chemical and mineralogical relationships with the parent rock. Observations, mainly resulting from exploration work in tropical weathered areas suggest an in-situ origin of the stone-line and/or the superficial layers, as proposed for example by Lecomte (1988) in Gabon. On the other hand, erosional-depositional processes are held 
responsible for the origin of stone-lines and overlying layers, as reported by Fölster (1969) in savannah-type regions of Africa and by Wells et al. (1990) in Madagascar. Allochthonous weathered material can intimately mix with autochthonous weathering products as observed within weathering mantles in Birma, Brazil and in the Philippines, where nickeliferous limonites above ultramafic rocks intermix with $\mathrm{Si}$ Al-rich weathering products in the upper parts of the profile (Schellmann, 1989; Marker et al., 1991).

The arguments favouring either an allochthonous or autochthonous origin of the weathering profiles thus are contradictory: profile sequences which show a distinct stratification with rather sharp boundaries between layers are unusual for an exclusively pedogenetic in-situ origin. Nevertheless even these profiles may reveal a distinct lithodependence of the surficial layers which has been explained by various authors by vertical action of soil organisms like termites and worms (e.g. De Ploey, 1964; Watson, 1974).

In the Paramirim Basin of Central Bahia, Brazil, yellowish-brown sandy-clayey soils and lateritic gravelly layers overlie migmatitic basement rocks of Archean age (Oliveira, 1983). Detailed investigations by Friedrich et al. (1987) led to the discovery of a concealed lithological contact between migmatite and a diabase dyke. Analyses of drillcore and testpit samples along a toposequence revealed clear differences regarding the composition of the weathering layers on both sides of the contact. Both autochthonous and allochthonous processes are held responsible for the formation of the weathering mantle in the Paramirim Basin (Friedrich et al., 1987; Marker, 1988). Parisot et al. (1989) however propose an in-situ origin for parts of the weathering mantle of the region.

The existence of autochthonous and allochthonous characteristic in weathering layers is of general relevance in scientific research and in mineral exploration. For this reason the study of the weathering mantle across the well exposed migmatite/ diabase contact was expected to contribute to the yet open question of the origin of complex weathering profiles.

\section{Geographical and geological setting}

The Paramirim Basin has a with of approximately $80 \mathrm{~km}$ and lies at an altitude of about $500 \mathrm{~m}$. It is flanked by the Serra de Magabeira in the E and the Serra de Macaubas in the W. The study area is located near Mocambo between the townships of Ibitiara and Ibipitanga (Fig. 1).

The climate of the region is semi-arid with an average annual rainfall of $700 \mathrm{~mm}$. The vegetational cover (caatinga) is dominated by thorny bushes.

The geomorphology of regional landscape is characterized by sequencial extensive pediplanes which are dissected by flat-floored valleys, forming shallow interfluves with gentle slopes.

The basement of the Paramirim Basin consists of undifferentiated migmatites of Archean age with local intrusions of mafic rocks. Weathering-resistant quartzite stocks form inselbergs whick emerge from the planation surface developed on the 

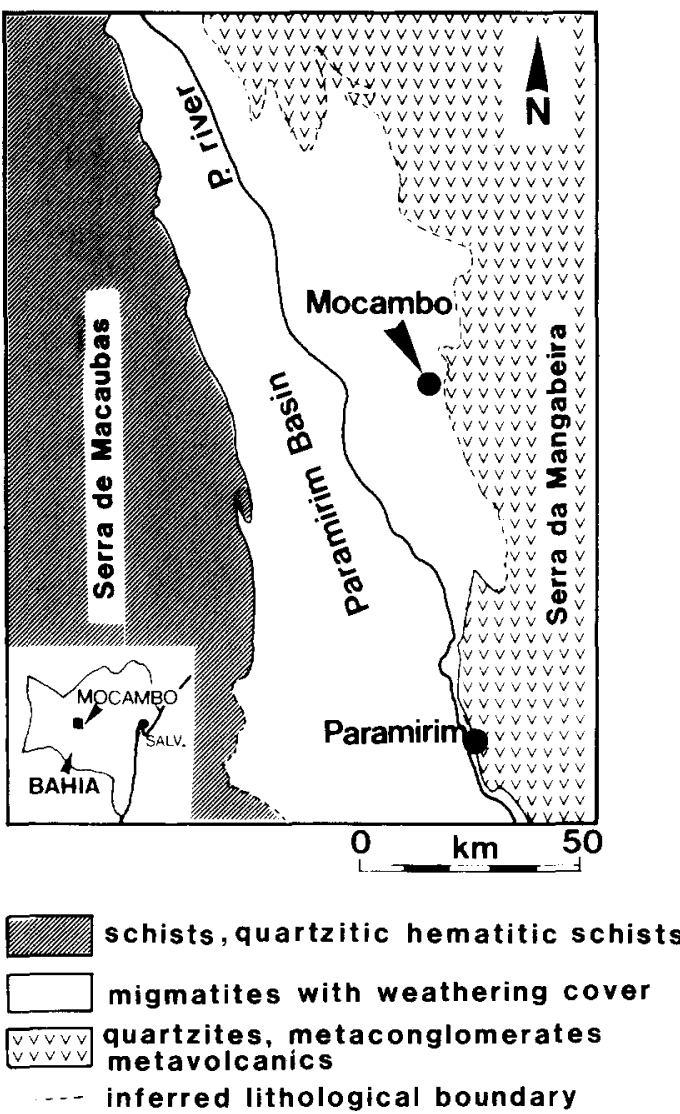

Fig. 1. Sketch map of the study area (after Inda and Barbosa, 1978).

migmatites. The flanking mountain ranges of Serra de Mangabeira and Serra de Macaubas are constituted of metasediments and metavolcanics of the Espinhaço Supergroup.

The migmatites in the Paramirim Basin are predominantly of granitic composition. The main mineralogical constituents are quartz, plagioclase, microcline, muscovite and biotite; accessory minerals are ilmenite, Ti-magnetite, zircon and rutile. Quartz crystals show cataclastic and patchwork patterns resulting from tectonical stress. Plagioclase crystals are strongly saussuritized (epidote, calcite, sericite, zoisite), which indicates retrograde metamorphism. Granitic migmatites are the parent rock of the testpits Mocambo (MOC) 2 and 3. The average chemical composition of four migmatite samples (R4, R5, R6, 2.5) is listed in Table 2.

Dykes and plugs of diabase occur throughout the Paramirim Basin. They are highly affected by metamorphism. The diabase encountered in testpit MOC 1 is composed of amphibole, plagioclase and pyroxene. Quartz, chlorite, epidote, biotite and carbonate are products of alteration during retrograde metamorphism. Fine-grained ilmenite, intensely intergrown with sphene and minor amounts of subhedral fine-grained zircon 
Table 1

Description of the weathering horizons and sample list

Sample Depth $(\mathrm{cm})$ Description

Testpit and drillhole $M O C 1$

$1.1 \quad 0-40 \quad$ reddish-brown loose sandy-clayey surface layer with pisolites in lower portion:

sandy material with few quartz fragments $>5 \mathrm{~mm}$

$1.240-130 \quad$ indurated upper part of reddish-brown laterite horizon with spongy-prismatic

texture; few quartz and quartzitic sandstone fragments

$1.3 \quad 130-220 \quad$ friable deeper part of reddish-brown laterite with few individual quartz fragments at the saprolite boundary

$1.4220-255$ reddish-green clayey saprolite; no preservation of rock texture (bottom of the testpit at $255 \mathrm{~cm}$ )

255-850 soft, clayey saprolite (not recovered in drillcore sample)

850-1120 slightly weathered diabase

$1.5 \quad 1050-1070$ drillcore sample of slightly weathered diabase

Testpit and drillhole MOC 2

$2.1 \quad 0-60 \quad$ yellowish-brown, loose sandy-clayey surface layer with silicious Fe-concretions

$2.260-130 \quad$ grain-supported gravel horizon with poorly sorted, angular to rounded quartz

fragments from few $\mathrm{mm}$ to $10 \mathrm{~cm}$ in size, cemented by ferruginous lateritic material

$2.3 \quad 130-170 \quad$ matrix-supported mottled lateritic horizon with fewer and smaller quartz fragments

$2.4 \quad 170-220 \quad$ friable saprolized migmatite with primary textures and abundant veins of

fragmented quartz

$2.5 \quad 320 \cdot 340 \quad$ drillcore sample of hard migmatite

Testpit MOC 3

$3.1 \quad 0.40 \quad$ yellowish-brown, loose sandy-clayey surface layer with siliceous Fe-concretions and angular and rounded quartz fragments

$3.2 \quad 40-60 \quad$ gravel horizon with lateritic matrix, consisting of poorly sorted angular quartz fragments from $<2 \mathrm{~mm}$ to $>10 \mathrm{~cm}$ in diameter, cemented by kaolinitic and ferruginous material

$3.3 \quad 60-180 \quad$ same material as above. but lateritic cement more ferruginous and quartz fragments

$3.4 \quad 180-200$ of higher angularity

R1, R2, R3 friable saprolized migmatite with primary textures and quartz veins

R4, R5, R6 diabase specimens from study area migmatite specimens from study area

constitute the accessory components of the diabase. The average chemical composition of three fresh diabase samples R1, R2, R3 is given in Table 2. sample 1.5 represents a slightly weathered diabase drillcore from profile MOC 1.

\section{Methods}

Channel samples (3-4 kg) of the principal weathering layers were collected in the three testpits MOC 1-3 (Table 1). Because of their high heterogeneity, the samples were separated in three fractions $>5 \mathrm{~mm}, 2-5 \mathrm{~mm}$ and $<2 \mathrm{~mm}$ by dry sieving. Quartz fragments were removed by hand from the fraction $>5 \mathrm{~mm}$. Subsequently, representative samples composed of material of the three size classes in quantities 
Table 2

Chemical composition (in weight $\%$ )

\begin{tabular}{lrrrrrrrrrr}
\hline $\begin{array}{l}\text { Sample } \\
\text { No. }\end{array}$ & $\mathrm{SiO}_{2}$ & $\mathrm{Al}_{2} \mathrm{O}_{3}$ & $\mathrm{Fe}_{2} \mathrm{O}_{3}$ & $\mathrm{TiO}_{2}$ & $\mathrm{MnO}$ & $\mathrm{MgO}$ & $\mathrm{CaO}$ & $\mathrm{Na}_{2} \mathrm{O}$ & $\mathrm{K}_{2} \mathrm{O}$ & LOI \\
\hline 1.1 & 80.8 & 7.0 & 5.6 & 0.75 & 0.04 & 0.08 & 0.12 & 0.16 & 0.32 & 4.6 \\
1.2 & 56.6 & 12.3 & 20.4 & 0.75 & 0.14 & 0.19 & 0.09 & 0.13 & 0.46 & 8.5 \\
1.3 & 61.9 & 12.1 & 15.5 & 0.88 & 0.30 & 0.12 & 0.09 & 0.19 & 0.46 & 7.9 \\
1.4 & 55.7 & 15.9 & 11.1 & 1.5 & 0.16 & 0.66 & 0.33 & 0.24 & 0.53 & 13.6 \\
1.5 & 49.5 & 12.4 & 14.9 & 2.2 & 0.19 & 4.1 & 8.6 & 2.0 & 0.56 & 5.0 \\
$\mathrm{R} 1-\mathrm{R} .3$ & 47.9 & 14.9 & 11.3 & 1.4 & 0.17 & 7.7 & 11.7 & 2.0 & 0.36 & 1.9 \\
2.1 & 84.2 & 6.8 & 3.4 & 0.53 & 0.02 & 0.14 & 0.10 & 0.11 & 0.35 & 4.0 \\
2.2 & 66.2 & 9.0 & 16.2 & 0.55 & 0.02 & 0.15 & 0.09 & 0.11 & 0.38 & 6.9 \\
2.3 & 61.1 & 9.4 & 19.2 & 0.59 & 0.34 & 0.18 & 0.08 & 0.22 & 0.44 & 7.9 \\
2.4 & 73.6 & 14.2 & 1.9 & 0.23 & 0.07 & 0.26 & 0.23 & 4.7 & 1.3 & 3.0 \\
2.5 & 73.3 & 15.5 & 1.4 & 0.12 & 0.02 & 0.35 & 0.44 & 5.4 & 1.8 & 1.4 \\
$\mathrm{R} 4 \cdots \mathrm{R} 6$ & 73.2 & 14.9 & 1.3 & 0.13 & 0.05 & 0.35 & 1.4 & 5.4 & 1.4 & 1.5 \\
3.1 & 89.1 & 4.0 & 2.6 & 0.31 & 0.01 & 0.17 & 0.08 & 0.33 & 0.26 & 2.7 \\
3.2 & 81.1 & 8.7 & 3.5 & 0.53 & 0.01 & 0.10 & 0.07 & 0.17 & 0.44 & 4.9 \\
3.3 & 74.3 & 9.2 & 8.8 & 0.54 & 0.01 & 0.13 & 0.07 & 0.25 & 0.44 & 5.9 \\
3.4 & 72.1 & 15.6 & 1.7 & 0.18 & 0.01 & 0.37 & 0.33 & 5.2 & 1.7 & 2.4 \\
\hline
\end{tabular}

Trace elements (in ppm)

\begin{tabular}{lrrrrrrrrrrrrrrr}
\hline $\begin{array}{l}\text { Sample } \\
\text { No. }\end{array}$ & $\mathrm{Ba}$ & $\mathrm{Ce}$ & $\mathrm{Co}$ & $\mathrm{Cr}$ & $\mathrm{Cu}$ & $\mathrm{Ga}$ & $\mathrm{Nb}$ & $\mathrm{Ni}$ & $\mathrm{Pb}$ & $\mathrm{Rb}$ & $\mathrm{Sr}$ & $\mathrm{V}$ & $\mathrm{Zn}$ & $\mathrm{Zr}$ \\
\hline 1.1 & 136 & $<35$ & 17 & 72 & 50 & 16 & 9 & 10 & $<10$ & 20 & $<5$ & 136 & 21 & 438 \\
1.2 & 388 & 123 & 20 & 107 & 114 & 21 & 8 & 17 & 37 & 32 & $<5$ & 428 & 25 & 309 \\
1.3 & 709 & 132 & 42 & 91 & 90 & 17 & 17 & 20 & 29 & 30 & $<5$ & 317 & 30 & 335 \\
1.4 & 489 & 73 & 33 & 94 & 93 & 28 & 17 & 33 & 24 & 43 & 16 & 260 & 53 & 259 \\
1.5 & 277 & $<35$ & 47 & 71 & 159 & 27 & 11 & 65 & $<10$ & 23 & 210 & 423 & 122 & 142 \\
$\mathrm{R} 1 \cdot \mathrm{R} 3$ & 263 & 34 & 61 & 467 & 84 & 22 & 13 & 131 & $<10$ & 13 & 246 & 290 & 85 & 105 \\
2.1 & 163 & 32 & 11 & 65 & 26 & 15 & 9 & $<7$ & $<10$ & 25 & $<5$ & 76 & 14 & 398 \\
2.2 & 144 & 29 & 7 & 94 & 62 & 14 & 9 & 10 & 22 & 28 & $<5$ & 332 & 17 & 322 \\
2.3 & 809 & 122 & 71 & 102 & 64 & 15 & 14 & 11 & 81 & 28 & $<5$ & 355 & 24 & 303 \\
2.4 & 607 & 116 & 72 & 36 & 14 & 20 & 6 & $<7$ & 11 & 45 & 100 & 37 & 14 & 136 \\
2.5 & 853 & 52 & 11 & 58 & $<10$ & 25 & 9 & $<7$ & 25 & 51 & 192 & 14 & 18 & 80 \\
$\mathrm{R} 4-\mathrm{R} 6$ & 638 & 32 & $<7$ & 47 & 13 & 22 & 5 & $<7$ & 19 & 41 & 280 & 7 & 40 & 83 \\
3.1 & 106 & $<35$ & 9 & 55 & 17 & 13 & 9 & $<7$ & $<10$ & 17 & $<5$ & 62 & 7 & 276 \\
3.2 & 165 & 62 & $<7$ & 69 & 21 & 15 & 12 & 8 & 15 & 31 & 7 & 89 & 16 & 355 \\
3.3 & 220 & $<35$ & 9 & 72 & 25 & 16 & 14 & 10 & $<10$ & 32 & $<5$ & 155 & 10 & 365 \\
3.4 & 702 & 44 & 14 & 63 & $<10$ & 23 & $<5$ & $<7$ & $<10$ & 51 & 178 & 23 & 17 & 67 \\
\hline
\end{tabular}

according to their relative proportions were prepared for geochemical and mineralogical analysis. Thus the analyses (Tables 2 and 3) refer to weathered material including quartz grains but excluding coarse quartz fragments.

All the samples were analyzed for 34 elements by XRF after fusion with 
Table 3

Mineralogical composition (XRD)

\begin{tabular}{|c|c|c|c|c|}
\hline $\begin{array}{l}\text { Sample } \\
\text { No. }\end{array}$ & Quartz & Kaolinite & Goethite & Other minerals \\
\hline 1.1 & $72 \%$ & $19 \%$ & $7 \%$ & \\
\hline 1.2 & $42 \%$ & $33 \%$ & $23 \%$ & \\
\hline 1.3 & $48 \%$ & $32 \%$ & $18 \%$ & \\
\hline 1.4 & $27 \%$ & $31 \%$ & $10 \%$ & $30 \%$ Smectite \\
\hline 1.5 & & & & Amphibole, Feldspar, Smectite, Quartz (Epidote) \\
\hline R1 R3 & & & & Amphibole, Feldspar, Chlorite (Epidote) \\
\hline 2.1 & $75 \%$ & $17 \%$ & $5 \%$ & $1 \%$ Feldspar \\
\hline 2.2 & $56 \%$ & $23 \%$ & $18 \%$ & $1 \%$ Feldspar \\
\hline 2.3 & $50 \%$ & $26 \%$ & $22 \%$ & \\
\hline 2.4 & $42 \%$ & $6 \%$ & - & $40 \%$ Feldspar; $10 \% \mathrm{Mica}$ \\
\hline 2.5 & & & & Feldspar, Quartz, Mica, (Smectite) \\
\hline B4 - R6 & & & & Feldspar, Quartz, Mica, (Chlorite) \\
\hline 3.1 & $80 \%$ & $13 \%$ & $3 \%$ & $2 \%$ Feldspar \\
\hline 3.2 & $70 \%$ & $22 \%$ & $4 \%$ & $2 \%$ Feldspar \\
\hline 3.3 & $63 \%$ & $20 \%$ & $10 \%$ & $5 \% \mathrm{Mica}$ \\
\hline 3.4 & $40 \%$ & $5 \%$ & - & $40 \%$ Feldspar; $13 \%$ Mica \\
\hline
\end{tabular}

$\mathrm{Li}$ - metaborate at $1250^{\circ} \mathrm{C}$. In addition to the elements listed in Table 2, As, Bi, Hf, Mo, P, Sn, Ta, Th, W and Y were analyzed. Their concentrations are either lower than the detection limits or do not show significant and interpretable variations. The mineralogical composition was qualitatively analyzed by XRD; the quantitative data in Table 3 were approximately calculated by means of chemical percentages.

Separation and analysis of heavy minerals (HM) as well as the quantification of HM contents were carried out according to the following method:

- desintegration of indurated samples by wooden mortar granulometric separation of size classes $<63 \mu \mathrm{m}, 63-355 \mu \mathrm{m}, 355-630 \mu \mathrm{m}$ and $630-1120 \mu \mathrm{m}$

- preconcentration of HM by MOZLEY shaking table (feed weight: $500-1000 \mathrm{~g}$ ) final HM-concentration by heavy liquids and preparation of polished sections

- magnetic separation of low-susceptibility HM (predominantely zircon) by Frantz separator for thin section analysis

\section{The weathering mantle}

The weathering mantle ("Terciario e Quarternario Detritico" after Inda and Barbosa, 1978) in the study area can be subdivided in three layers (Fig. 2): the homogeneous, loose sandy-calyey surface layer has a yellowish-brown colour above the migmatite changing to a reddish-brown colour above the diabase. Granulometric analyses of this layer revealed that $60-70 \mathrm{wt} \%$ of the weathering material is coarser than $30 \mu \mathrm{m}$ and that up to a maximum of $13 \mathrm{wt} \%$ consists of components with 


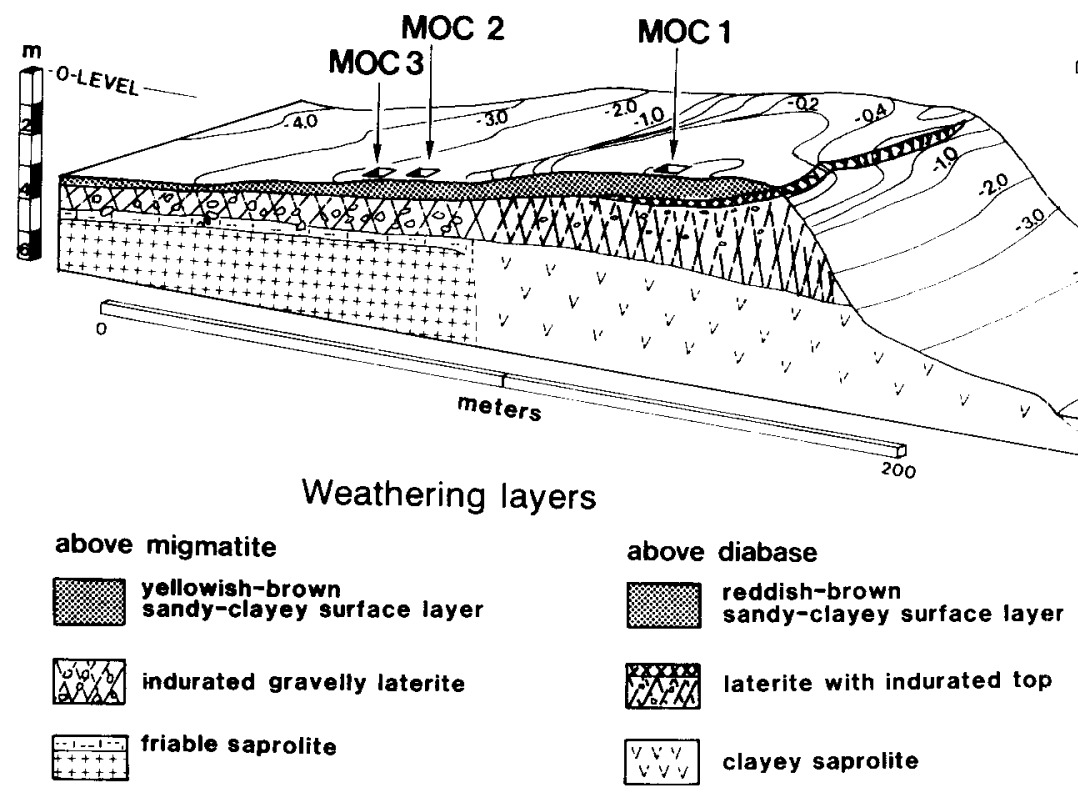

Fig. 2. Toposequence of weathering horizons above the migmatite-diabase contact at Mocambo, Central Bahia.

diameters above $10 \mathrm{~mm}$. The fraction $>30 \mu \mathrm{m}$ essentially is composed of quartz whereas the fraction $<30 \mu \mathrm{m}$ consists of goethite and kaolinite (Friedrich et al., 1987).

The underlying indurated laterite layer is rather heterogeneous and shows high abundance of up to $70 \mathrm{wt} \%$ quartz gravels embedded in a sandy-friable ferruginous matrix above the migmatite, grading to predominantely indurated ferruginous material with only few quartz fragments above the diabase. The gravel consists of fragments derived from quartz veins. Quartzitic sandstone fragments and nodular Fesilica concretions almost exclusively occur in profile MOC 1 . Within the laterite layer, the average grain size of the gravel increases downward.

The transition from the diabase-derived profile to the migmatite-derived profiles is gradual and lies within a distance of less than $10 \mathrm{~m}$.

The gravelly indurated laterite layers are underlain by a thin $(<0.5 \mathrm{~m})$ and friable saprolite above the migmatite and a thick $(>6 \mathrm{~m})$ soft clayey saprolite above the diabase.

\subsection{Chemical and mineralogical composition}

The composition of the three weathering layers (Tables 2 and 3) shows distinct relations to the composition of the underlying parent rocks. This relationship is reflected rather by the chemical than by the mineralogical composition of the material. Furthermore, the geochemical signal of the underlying rock diminishes from the bottom towards the top of the profile. Thus the saprolite samples above 


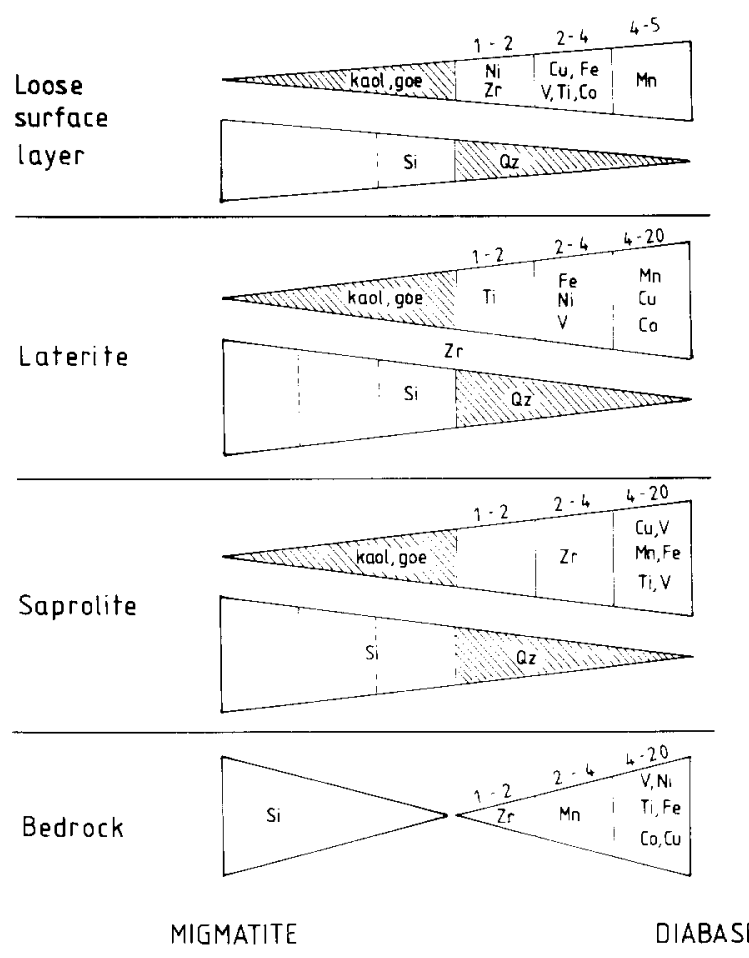

Fig. 3. Variation of concentration of selected elements in weathering layers across the migmatite-diabase contact; numbers indicate concentration ratios of elements in weathering material above the diabase (MOC 1) in comparison to material above the migmatite (MOC 3).

diabase and migmatite reveal a distinct compositional relationship with the parent rock whereas the surface layers only slightly reflect parent rock composition.

The upper saprolite above the diabase is characterized by nearly complete decomposition of primary minerals and formation of kaolinite, smectite and goethite. This mineral transformation is chemically indicated by a strong loss of $\mathrm{Na}, \mathrm{Ca}, \mathrm{Mg}, \mathrm{Sr}, \mathrm{Cr}$ and $\mathrm{Ni}$. The anomalous increase in $\mathrm{Si}$ above the nearly quartz-free diabase (Sample $\mathrm{R} 1, \mathrm{R} 2, \mathrm{R} 3,1.5$ ) is due to the abundance of detrital quartz grains. In the laterite horizon above the diabase, smectite disappears whereas goethite and also quartz become more abundant. Si, Fe, Ba, Ce, V and $\mathrm{Zr}$ increase and $\mathrm{Al}, \mathrm{Ti}, \mathrm{Mg}, \mathrm{Ca}$, na, $\mathrm{Ni}$ and $\mathrm{Sr}$ decrease. The losse surface layer is markerd by an increase of Si (quartz) and $\mathrm{Zr}$; the other minerals and nearly all other elements show lower contents resulting from the dilution effect of quartz.

Although the correlate layers in the profiles above migmatite and diabase show deviating element concentrations, the distribution trends of the elements are identical, especially the increase of quartz contents towards the surface. The saprolite samples on migmatite are composed of quartz, feldspar, mica and minor kaolinite. Only $\mathrm{Ca}$ is strongly depleted due to kaolinisation of $\mathrm{Ca}$-rich feldspar. In the ferruginous cement of the overlying indurated gravelly laterite layers, feldspar and mica usually are 
decomposed and replaced by goethite and kaolinite. This mineral transformation is accompanied by a strong loss of alkalies and alkaline earths whereas $\mathrm{Fe}, \mathrm{Ti}, \mathrm{Cr}, \mathrm{Cu}, \mathrm{V}$ and $\mathrm{Zr}$ contents increase. The loose surface layer is charcterized by high quartz contents and low contents of goethite.

The lateral change (Fig. 3) in the main element composition of the weathering layers is clearly reflected by the increase of $\mathrm{Si}$ - and the decrease of Fe-content from the diabase towards the migmatite, which is accompanied by an increase of quartz and decrease of kaolinite and goethite. The loose surface layer above the diabase contains nearly twice as much Fe and 4 to 5 times as much $\mathrm{Mn}$ as the corresponding layer above migmatite. Amongst the trace elements which show a systematical change along the toposequence, $\mathrm{Mn}, \mathrm{Cu}, \mathrm{V}, \mathrm{Ti}$ and $\mathrm{Co}$ attain significantly higher values above the diabase. The chemical differences are more pronounced between the testpits MOC 1 and 3 than between the neighboured testpits MOC 1 and 2, indicating a gradual dispersion of chemical features of the diabase towards the migmatite and vice versa.

Chemical differences become more distinct in the laterite horizon, where $\mathrm{Mn}, \mathrm{Co}$ and $\mathrm{Cu}$ represent the discriminating elements with values 4 to 20 times higher above the diabase than above the migmatite. In the saprolite, chemical differences are even more explict with almost all diabase-typical elements showing higher concentrations above the diabase. $\mathrm{Zr}$ reveals a rather indifferent behaviour due to bonding to detrital zircon, which in spite of lower $\mathrm{Zr}$-contents is much more abundant in the migmatite than in the diabase (see below).

Thin section analyses of weathering material from the diabase and migmatite show that quartz occurs predominantly in form of detrital, angular, splintery grains; minor amounts of subangular to subrounded grains can be observed. The grain size varies in a wide range between $25-2000 \mu \mathrm{m}$ with a predominance at approximately $50 \mu \mathrm{m}$. In the weathering profile on diabase the mean grain size increases with approach to the surface; no secondary quartz has been observed. Many quartz grains show corrosion features with solution cavities and partial replacement or impregnation by kaolinite and goethite.

\subsection{Heavy minerals}

The microscopic identification of heavy minerals (HM) based on the following characteristics:

Zircon 1 occurs mostly as coarse euhedral prismatic grains, often showing zonation and desintegration along radiogenic cracks, which are healed by goethite; zircon 2 forms coarse rounded and lobate subhedral grains and zircon 3 forms fine splintery grains of diameters $<50 \mu \mathrm{m}$.

IImenite is characteristically euhedral to subhedral and shows distict anisotropy and pinkish-brown colours.

Ti-magnetite is distinguished from ilmenite by lack of anisotropy and slightly higher reflectivity.

"Weathered Fe-Ti-oxides" refers to ilmenite and Ti-magnetite which due to 
Table 4

Total contents of heavy minerals (in weight $\%$ ) and relative distribution (in volumle $\%$ )

\begin{tabular}{|c|c|c|c|c|c|c|}
\hline Heavy mineral content & MOC 1.1 & MOC 1.3 & MOC 1.4 & MOC 3.1 & MOC 3.3 & MOC 3.4 \\
\hline Heavy mineral content & 0.059 & 0.020 & 0.017 & 0.097 & 0.034 & 0.010 \\
\hline Zircon & 48 & 34 & 22 & 23 & 37 & 15 \\
\hline Ilmenite & 16 & 16 & 29 & 13 & 38 & 5 \\
\hline Ti-magnetite & 20 & 23 & 20 & 11 & & 5 \\
\hline Fe-Ti-oxides, weathered & 10 & 17 & 15 & 45 & 17 & 71 \\
\hline Rutile & 4 & 5 & 7 & 3 & 8 & 2 \\
\hline Leucoxene & 2 & 5 & 7 & 5 & - & 2 \\
\hline Total & 100 & 100 & 100 & 100 & 100 & 100 \\
\hline
\end{tabular}

weathering alteration can no longer be distinguished by their optical properties like anisotropy, reflectivity and colour; both show partial replacement by leucoxene along fissures and grain margins.

Leucoxene forms individual aggregates of sphene intergrown with goethite and anatase.

Rutile is typically euhedral with bright red to orange-yellow internal reflections.

The HM association of the diabase from testpit MOC 1 is dominated by ilmenite which is partly replaced by sphene, forming ilmenite-sphene aggregates with patchlike intergrowth textures (Friedrich et al., 1987). Minor amounts of fine-grained transparent HM of high relief and birefringence, referred to as Zircon 3 can be observed.

The HM association of the migmatite from testpit MOC 3 is mainly composed of coarse grained $(150-300 \mu \mathrm{m}$ ) euhedral to rounded lobate zircon crystals ( $34 \mathrm{Vol} \%$ ) and coarse ilmenite and Ti-magnetite, which in many cases are weathered to leucoxene along orientated fractures $(61 \mathrm{Vol} \%)$. Minor amounts of coarse rutile and leucoxene aggregates can be observed (Friedrich et al., 1987).

The microscopic analysis of HM from the saprolite of MOC 1 (Table 4) reveals high abundances of zircon 1 and 2 (referred to as "zircon" in Table 4), coarse-grained ilmenite and Ti-magnetite. As described above, these minerals have not been observed in the diabase. The saprolite of MOC 3 essentially shows the same HM as detected in the migmatite bedroch with slightly varying proportions.

In MOC 1, the relative proportions of zircon increase from the laterite layer towards the loose surface layer, where this mineral attains a maximum content of $48 \mathrm{Vol} \%$ (Table 4). Fine-grained ilmenite-sphene aggregates which represent the principal HM of the diabase bedrock, could not be observed in the weathering material of MOC 1, probably due to replacement by leucoxene.

In MOC 3, the highest proportions of weathered $\mathrm{Fe}-\mathrm{Ti}$-oxides are encountered in the saprolite and loose surface layer (MOC 3.1, MOC 3.3), whereas zircon attains its maximum content in the laterite layer (MOC 3.3 in Table 4).

The total heavy mineral contents attain their highest values in the loose surface layers of MOC 1 and 3, decreasing with depth (Table 4). HM are concentrated in the grain size fraction $63-355 \mu \mathrm{m}$. The fraction $<63 \mu \mathrm{m}$ contains only minute amounts of $\mathrm{HM}$. 
The occurrence of corroded zircon and $\mathrm{Fe}$-Ti-oxides indicate advanced weathering of the heavy minerals. Furthermore the correlation of the $\mathrm{Zr}$-contents of the bulk analyses with the contens of zircon minerals in the weathering products revealed a significant discrepancy: the identified zircon minerals can only account for a minor part of the total $\mathrm{Zr}$-content (136-435 ppm) of the bulk weathering material. This fact indicates that $\mathrm{Zr}$ may also present in (not identified) very minute zircon relics or fixed in secondary minerals (Carrol, 1953; Saxena, 1966).

\section{Discussion}

The discussion of the field observations and analytical data should lead to a genetic model which can interpret the origin of the weathering cover in accordance with wellknown processes as easily as possible. The following important features of the profiles shall be considered before presenting a genetic model for the origin of the weathering mantle in the Paramirim Basin:

- The abundance of detrital quartz and extraneous HM like zircon, rutile and ilmenite in the saprolite, laterite and loose surface layer above the diabase indicates a lateral mechanical dispersion of migmatite-derived siallitic material into the weathering products above the diabase. This transport must have already occurred during initial weathering stages. The proportions of siallitic material increases towards the profile top.

Lithodependence of the weathering products is predominantely reflected by their chemical composition, showing significantely higher concentrations of $\mathrm{Fe}, \mathrm{V}, \mathrm{Mn}$, $\mathrm{Cu}, \mathrm{Co}$ and $\mathrm{Ni}$ above the diabase. The decreasing concentrations of these elements towards the profile top are the result of dilution by quartz-rich siallitic material imported from the migmatites.

In the laterite layer, chemical dispersion of $\mathrm{Mn}, \mathrm{Cu}, \mathrm{Co}, \mathrm{Fe}, \mathrm{Ni}$ and $\mathrm{V}$ from the diabase (MOC 1) towards the migmatite (MOC 2,3) is reflected by gradually decreasing contents of these elements with increasing distance from the diabase.

The accumulation of quartz fragments above the migmatite can be related to the occurrence of quartz veins which are abundant in the migmatite but absent in the diabase.

After consideration of these features it has to be assumed, that the weathering profile above the diabase is a product of mechanical intermixing of diabase- and migmatite-derived weathering material. The $\mathrm{Mn}-\mathrm{Co}-\mathrm{Cu}-\mathrm{Fe}-\mathrm{Ni}-\mathrm{V}$ halo in the laterite layer which extends from the diabase onto the migmatite, results from hydromorphic dispersion during lateritisation. The strong coherence in grain size, chemical and mineralogical composition between loose surface layer and underlying laterite leads to the conclusion, that the surface layer represents the degradation product of the underlying laterite, while bioturbation may have played an important role in the destruction of the indurated laterite and the vertical redistribution of the material.

The following genetic concept is proposed: 
(1) Weathering results in the formation of a deep, clayey saprolite above the diabase and a thin kaolinitic saprolite above the migmatite. The difference in thickness is due to the higher weatherability of the mafic rock.

Smectite formation above the diabase and the weak kaolinisation of the migmatite indicate restricted weathering conditions with only moderate drainage. During this phase, periodic heavy rainfall induces surface wash with lateral redistribution of eroded material. Clay minerals are washed out and carried over longer distances into low lying areas. The sedimentary supply of residual quartz grains from the weathering mantle of the migmatite leads to intermixing with diabase-derived saprolitic material above the diabase.

The lateral redistribution is accompanied by vertical transfer wherby preferentially finer grains are spilled downward in open spaces and voids of the upper saprolite. This contributes to the high quartz and zircon contents in the laterite and upper saprolite above the diabase. It is assumed that the sedimentary redistribution runs parallel with continous weathering.

The accumulation of subangular to subrounded, poorly sorted quartz fragments above the migmatite is due to the removal of finer material, leaving behind a skeleton of grain supported coarse fragments derived from quartz veins which have desintegrated and collapsed during weathering. The removal of fine material may be due to surface wash. In addition the accumulation of quartz boulders and fragments can be explained by participation of termites, which carry finer material $<2 \mathrm{~mm}$ to the surface for the construction of termite mounds. Separation of coarse and fine material by differential movement and chemical digestion, as proposed by Lecomte (1988) finds no direct evidence in the studied profiles.

(2) Lateritic weathering conditions lead to ferruginous cementation of the gravel layer above the migmatite and lateritisation of partly transported material, thus forming the lateritic hardcrust above the diabase. During this phase, hydromorphic dispersion of $\mathrm{Mn}, \mathrm{Cu}, \mathrm{Co}, \mathrm{Fe}$ and $\mathrm{Ni}$ results in a geochemical halo which extends from the diabase to the migmatite.

(3) Degradation of the indurated laterite layer by erosion, insolation and bioturbation gives rise to the formation of the loose surface layer. During degradation, fine material is washed out, leading to a further residual enrichment of the sand fraction as reflected by the relative increase of HM and quartz. The participation of termites which carry sandy material from the gravel layer towards the surface has to be taken into consideration for the origin of the surface layer and finds support in the observations of Freyssinet et al. (1990), who stated that elevated Au-contents in silty surface layers of Mali are due to upward transport of mineral matter by termites.

Thus colluvial transport, chemical dispersion and vertical biogenetic redistribution transform the weathering mantle, whereby the chemical and mineralogical characteristics of the parent rock are more and more obscured towards the top of the profile.

The postulated participation of termites cannot be proven by actual field observations. In the study area no termite mounds were observed, whereas in elevated adjacent areas they are very widespread. 
The relative contribution of the various discussed processes to the formation of the weathering mantle is crucial for interpretation of lithodependence and therefore relevant for geochemical exploration. Lithodependence is obliterated by lateral mechanical contribution, intermixing and redistribution of mineral matter, while vertically operating processes like chemical weathering and action of termites may have favoured the transmission of geochemical signals ( $\mathrm{Fe},>\mathrm{Ti}, \mathrm{Mn}, \mathrm{V}, \mathrm{Cu}, \mathrm{Ni}, \mathrm{Co}$ ) of the diabase bedrock onto the loose surface layer.

Weathering sequences similar to the discussed weathering horizons in the Paramirim Basin can be expected in semi-arid areas with sparse vegetation, low to moderate annual precipitation but occasionally heavy rainfall. Under these conditions lateritisation is relatively weak, but the redistribution of the weathering products by colluvial processes, resulting in the intermixing of autochthonous and transported material and possibly the action of termites should be very pronounced.

\section{References}

Carrol, D., 1953. Weatherability of zircon. J. Sediment. Petrol., 23(2): 106-116.

De Ploey, J., 1964. Nappes de gravats e couvertures sableuses du Bas-Congo, leur genèse et l'action des termites. Int. Coll. Univ. Lovanium, Kinshasa, Zaire: 399-414.

Fölster, H., 1969. Slope development in SW-Nigeria during late Pleistocene and Holocene. Göttinger Bodenkundl. Ber., 10: 3-56.

Freyssinet, P., Roquin, C., Muller, J.C., Paquet, H. and Tardy, Y., 1990. Geochemistry and mineralogy of soils covering laterites and their use for gold exploration. Chem. Geol., 84: 58-60.

Friedrich, G., Marker, A., Kanig, M. and Germann, A., 1987. Mineral prospecting and geological mappinq in laterite covered areas of Brazil. BMFT RG 83015 Final Report, Institut für Mineralogie. RWTH Aachen. 375 pp.

Inda, H.A.V. and Barbosa, J.F., 1978. Texto explicativo para o Mapa Geológico do Estado da Bahia. SME/CPM, Salvador, $122 \mathrm{pp}$.

Lecomte, P., 1988. Stone line profiles: Importance in geochemical exploration. J. Geochem. Explor.. 30: $35-61$.

Marker, A., 1988. lateritische Verwitterungsdecken über ultramafischen Gesteinskomplexen in Brasilien und den Philippinen. Unpublished Ph. D. thesis, Institut für Mineralogie, RWTH Aachen, $319 \mathrm{pp}$.

Marker, A., Friedrich, G., Carvalho, A. and Melfi, A., 1991. Control of the distribution of Mn. Co, Zn, Zr, $\mathrm{Ti}$ and REE during the evolution of lateritic covers above ultramafic complexes. J. Geochem. Explor: 40: $361-383$.

Oliveira, J.J.. 1983. Lateritic soil profiles in semiarid environment: Pedological, geochemical and mineralogical data. In: Proc. II. Int. Sem. Lateritisation Processes, Sao Paulo, 1982, pp. 499-506.

Parisot, J.C.. Soubies, F., Audry, P. and Espourteille, F., 1989. Some implications of lateritic weathering on geochemical prospection - two Brazilian examples. J. Geochem. Explor., 32: 133-147.

Saxena, K.A., 1966. Evolution of zircons in sedimentary and metamorphic rocks. Sedimentology, 6: 1-33.

Schellmann, W., 1989. Allochthonous surface alteration of Ni-laterites. Chem. Geol., 74: 351364.

Watson, J.P. . 1974. Termites in relation to soil formation, groundwater and geochemical prospecting. Soils Fert. 37: 111-114.

Wells, N.A., Andriamihaja, B. and Rakotovololona, H.F.S., 1990. Stonelines and landscape development on the laterized craton of Madagascar. Geol. Soc. Am. Bull., 102: 615-627. 